\title{
INDUSTRIAL REVOLUTION 4.0: AND THE IMPACT ON HUMAN RESOURCES
}

\author{
Nova Jayanti Harahap \\ Dosen Fakultas Ekonomi dan Bisnis Universitas Labuhanbatu \\ e-mail:novazhrp@gmail.com \\ Mulya Rafika \\ Dosen Fakultas Ekonomi dan Bisnis Universitas Labuhanbatu \\ e-mail: Mulya_rafika@yahoo.co.id
}

\begin{abstract}
Indonesia began to face the Industrial 4.0 era, where all systems began to be connected digitally. This condition is inseparable from the rapid development of industrial scientific knowledge. Through a literature study, this paper aims to look at the data quality approach regarding how the emergence of Industry 4.0 is related to the development of industrial engineering science, what challenges are faced and how the government should direct the development of industry 4.0. The results of this study indicate that in its development, the 4.0 industrial revolution had an influence on human resources to evolve to the emergence of the idea of Industry 4.0. The idea brought the concept of combining digital technology and the internet with conventional industry which ultimately aims to increase productivity, efficiency and reduce the number of unemployed significantly. However, aside from that, some of the consequences faced are related to the negative impacts of Industry 4.0 in which impacts on human resources. This is where various challenges arise for the government. There are many roles that the government can play to face the challenges of the emergence of Industry 4.0. The main role is to focus on equipping human resources by expanding employment and also providing opportunities to be able to open entrepreneurship in various business places such as, in individual business centers and in the vicinity of franchise businesses.
\end{abstract}

Keywords: Government Ways to Overcome Unemployment, Industrial Revolution 4.0, Literature Study.

\section{INTRODUCTION}

The world has entered the era of the industrial revolution 4.0 seems no longer just a discourse. Various technologies that are signs of the start of the industrial revolution 4.0, have begun to be applied in various places. One of them is artificial intelligence (AI) or artificial intelligence that is growing at this time. Not only for industry, AI was also developed to facilitate human life in other aspects. The atmosphere of the changing relationship between people has changed quite quickly with the presence of technological developments. Technological developments that are able to change the pattern of relationships between people in all aspects of social life in terms of social, economic, legal, political and cultural aspects as well as security. 
Changes from various skin touches, such as face to face to touch the screen, screen to screen, virtual relations with various window dressings that are carried out automatically and robotically. A change that inevitably has to be handled wisely and wisely in order to produce output that is positive. The atmosphere that necessitates a change in mindset, ways of working, and patterns of building harmonious relationships between community groups and organizations.

This phase of change is known as the Industrial Revolution 4.0, a phase that is generally about automation and exchange of data in factory technology, robotic and artificial intelligence. The phase that ultimately results in "Smart Process". In the Smart Process modular, algorithms, physical-cyber systems monitor physical processes, create copies of the physical world virtually, and make decentralized decisions. Technological sophistication that we cannot negate in social life let alone in the business world. In the business world, this change needs to be addressed quickly and with careful preparation. Anticipatory steps become imperative to be done both in terms of business processes and relationships within the company so that the existence of change is maintained.

The times need to adjust to business processes and market needs effectively and efficiently in order to be able to provide significant added value for the company. Treatment of human resources is also a very important concern for the company. In addition, changes in industrial relations also need to be built in harmony so that the achievement of company goals can be jointly carried out. Both business processes, human resource management and industrial relations need to be carried out in parallel. Given the impact of the industrial revolution 4.0 is very closely related to these three aspects.

From the explanation of Industry 4.0 which is closely related to the production process, its presence is inseparable from the influence of industrial engineering knowledge. Industrial engineering science since the industrial revolution era developed rapidly into modern times. The scope of the study that was originally narrow has become increasingly broad. This condition raises the question whether the development of industry 4.0 has a negative impact on small traders or profitable?

This paper attempts to answer these questions by digging through literature studies and at the same time providing advice on the direction of industrial development 4.0.

\section{METHOD}

Based on the background above, this paper tries to see the problem from the standpoint of the philosophy of science about how the actual emergence of Industry 4.0 if it is related to the development of industrial engineering knowledge and what challenges are faced by small traders regarding the presence of Industry 4.0. The steps taken are as follows, (1) collecting information through literature books, articles and websites related to the philosophy of science, scientific development of Industry 4.0, (2) attracting the relationship between small traders and the emergence of Industry 4.0 phenomena, (3) compiling a picture of challenges that will be faced by small traders in dealing with industry 4.0, (4) giving 
advice to the government to deal with small traders and unemployment due to the development of industry 4.0.

The concept of the industrial revolution 4.0 is a concept that was first introduced by Professor Klaus Schwab. He is a well-known economist from Germany as well as the originator of the World Economic Forum (WEF), which through his book, The Fourth Industrial Revolution, states that the 4.0 industrial revolution could fundamentally change the way we live, work and relate to one another.

In his presentation, one of the lecturers at the Bandung Institute of Technology (ITB), Richard Mengko, quoted from A.T. Kearney, uncovered the history of the industrial revolution until it finally touched this 4th generation. Here are four stages of industrial evolution from the past to the present.

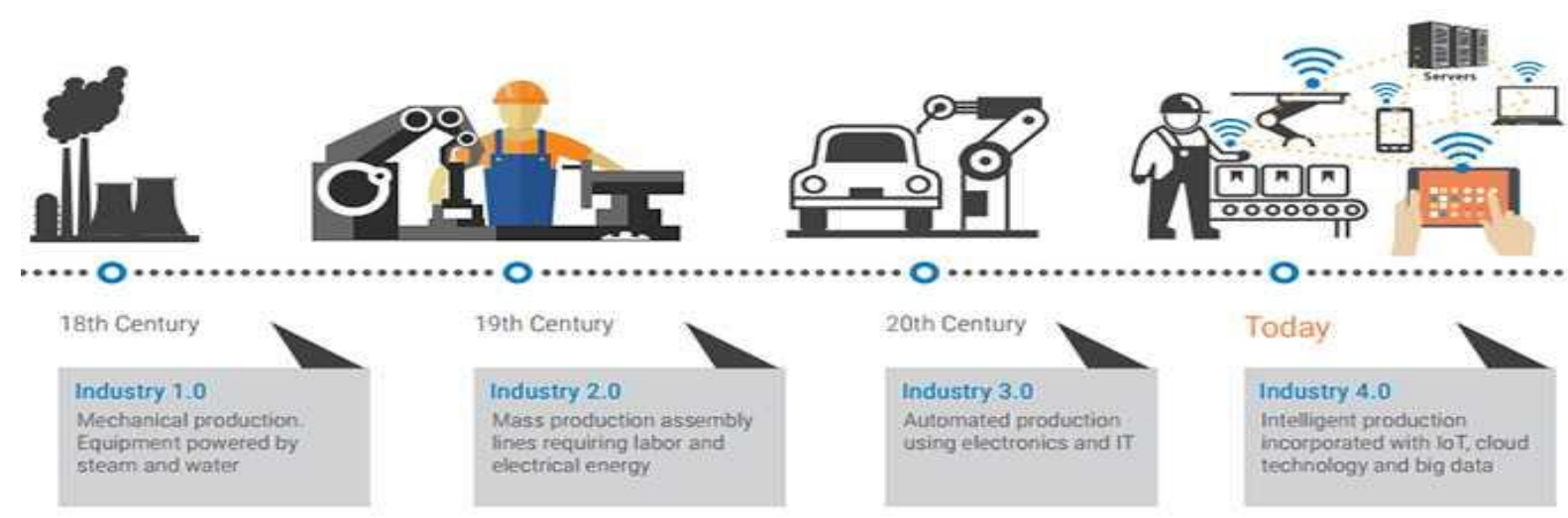

1. The first industrial revolution took place at the end of the 18th century. This was marked by the discovery of the first mechanical loom in 1784. At that time, the industry was introduced to mechanical production facilities that used hydropower and steam. Work equipment that initially relied on human and animal power was eventually replaced by the machine. As a result, despite increasing production, many people are unemployed.

2. The industrial revolution 2.0 occurred at the beginning of the 20th century. At that time there was the introduction of mass production based on the division of labor. This mass production is made possible by the presence of electricity and assembly lines. The first production line involved abattoirs in Cincinnati, United States, in 1870.

3. Beginning in 1970 is suspected as the inaugural appearance of the 3.0 industrial revolution that began with the use of electronics and information technology for production automation. The debut of the third generation industrial revolution was marked by the appearance of the first programmable logic controller (PLC), the modem 084-969. This computer-based automation system makes industrial machines no longer human-controlled. Production costs can be reduced due to the application of this.

4. Beginning in 2018 until now, the era of the industrial revolution 4.0. is an industry that combines automation technology with cyber technology. This is a trend of automation and data exchange in manufacturing technology. In this era, industry began to touch the virtual 
world, in the form of human, machine and data connectivity, all of which were everywhere. This term is known as the Internet of Things (IoT).

\section{RESULTS AND DISCUSSION}

\subsection{Development of Industrial Revousi 4.0}

Technological advancements make automation possible in almost all fields. New technologies and approaches that combine the physical, digital and biological world will fundamentally change the pattern of life and human interaction (Tjandrawinata, 2016).

Industry 4.0 as a phase of the technological revolution changes the way in which human activities take place in scale, scope, complexity, and transformation from previous life experiences. Humans will even live in global uncertainty, therefore humans must have the ability to predict the fast changing future. Each country must respond to these changes in an integrated and comprehensive manner. The response involved all global political stakeholders, ranging from the public sector, private sector, academia, to civil society so that industry challenges 4.0 can be managed into opportunities.

\subsection{Industrial Revolution 4.0 and its relation to Human Resources}

The fourth era of industrial revolution (Industry 4.0) is increasingly felt in Indonesia. This revolution allows the industry to integrate products produced with high automation technology and the internet.

Professor Klaus Schwab as the initiator of the World Economic Forum (WEF) through his book The Fourth Industrial Revolution states, this revolution can fundamentally change the way we live, work and relate to one another. The fourth industrial revolution can increase the rate of information mobility, the efficiency of industrial organizations, and help minimize environmental damage.

The Industrial Revolution is now being felt in Indonesia, one of them is in the form of digitizing the transportation service sector in Indonesia, which can be seen from the presence of online taxis and motorcycle taxis. Both can provide services between both goods and people without having a single transportation fleet used in their services. However, this revolution did not come without bringing new problems. Call it the inability of the government to make regulations related to business models with new technology, social fragmentation and potentially widening economic inequality.

Rational consumers are more willing to choose goods with lower prices produced in the market. Through digitalization, the goods provided will be cheaper because of the use of space, labor, and goods traded using a mechanism that is more efficient than conventional ones. Do not forget to evolve startup business models in this era with the mechanism of burning money able to provide attractive discounts and promos that are certainly not offered by conventional. 
The presence of online transportation in addition to providing opportunities for creating new jobs also risks creating new unemployment if it can not be anticipated. Conventional transportation drivers such as base taxi drivers, public transportation, and taxis have the opportunity to enter the unemployment gap due to the emergence of online transportation which is considered to be much cheaper and more comfortable in the eyes of the public today.

Not just conventional transportation company drivers, we still haven't talked about the possibility of laying off employees due to the company's revenue drop. Similar to conventional transportation service providers, traders in traditional kiosks are being displaced by the wave of e-commerce through the emergence of various online shops. Traders lose out and end up bankrupt because online stores provide goods that are more varied, cheaper, and easily accessible.

The two examples above have been able to indicate how digitalization that was part of the 4.0 industrial revolution began to shift the conventional role in the market. Not only digitalization, in the future the use of robots in supporting autonomy in the realm of the manufacturing and service industries will be increasingly inevitable. This is driven by the company's desire to cut costs caused by human resources. The demand for wage increases that is not accompanied by productivity is one of the problems that are often experienced by companies related to human resources.

Technological developments that will sooner or later affect the demand for labor in the future. In the future labor demand will shift. Industries will tend to choose middle and highly skilled labor rather than less-skilled labor because their role in doing repetition work can be replaced by autonomous robots.

\subsection{Challenges Faced Regarding the Development of the Industrial Revolution 4.0}

The fourth generation industrial revolution not only provides opportunities, but also challenges for millennial. The progress of science and technology as a trigger for the industrial revolution was also followed by other implications such as unemployment, human vs. machine competition, and demands for increasingly high competencies.

According to Prof. Dwikorita Karnawati (2017), the 4.0 industrial revolution in the next five years will erase 35 percent of jobs. And even in the next 10 years the type of work that will be lost increases to 75 percent. This is due to the work being played by humans step by step being replaced with program digitizing technology. As a result, the production process is faster and easier to distribute massively with minimal human involvement. In the United States, for example, the development of an online banking system has facilitated the transaction process for banking services. As a result, 48,000 bank tellers had to face termination due to efficiency reasons.

According to the McKinsey survey, a multinational management consulting corporation, in Indonesia as many as $\mathbf{5 2 . 6}$ million jobs could potentially be replaced by digital 
systems. In other words, 52 percent of the workforce or representing 52.6 million people will lose their jobs.

Wolter identified the challenges of industry 4.0 as follows; 1) information technology security issues; 2) the reliability and stability of the production machine; 3) lack of adequate skills; 4) unwillingness to change by stakeholders; and 5) the loss of a lot of work because it turns into automation (Sung, 2017).

Irianto (2017) simplifies industry 4.0 challenges namely; (1) industry readiness; (2) trusted workforce; (3) ease of socio-cultural regulation; and (4) diversification and job creation and industry opportunities 4.0 namely; (1) ecosystem innovation; (2) competitive industrial base; (3) investment in technology; and (4) integration of Small and Medium Enterprises (SMEs) and entrepreneurship.

The Mapping challenges and opportunities of industry 4.0 to prevent various impacts on people's lives, one of which is the problem of unemployment. Work Employment and Social Outlook Trend 2017 predicts the number of unemployed people globally in 2018 is expected to reach 204 million with an additional increase of 2.7 million. Almost the same as the conditions experienced by western countries, Indonesia is also predicted to experience the same thing. Unemployment is also still a challenge and even tends to be a threat. Indonesia's open unemployment rate in February 2017 was 5.33\% or 7.01 million of the total 131.55 million workforce (Source: BPS 2017).

2017 BPS data also shows, the number of unemployed people who came from the Vocational High School (SMK) was in the top rank of 9.27\%. Next is the high school graduates (SMA) by 7.03\%, Diploma III (D3) by 6.35\%, and universities $4.98 \%$. Identified, the cause of the high contribution of vocational education to the number of unemployed in Indonesia is one of them caused by the low special skills and soft skills possessed.

The problem of unemployment and competitiveness of human resources is a real challenge for Indonesia. The challenges facing Indonesia are also compounded by the demands of companies and industry. The World Bank (2017) reported that the labor market requires multi-skills graduates who are forged by education units and systems, both secondary education and higher education.

Indonesia is also predicted to experience a demographic bonus in 2030-2040, namely the population of productive age is more than the non-productive population. The population of productive age is estimated to reach $64 \%$ of the total population of Indonesia, which is estimated at 297 million. Therefore, the large number of people of productive age must be followed by improvements in quality, both in terms of education, skills and competitiveness in the labor market.

\subsection{Suggestions Towards the Direction of Industrial Development 4.0 with Human Resources}

There are 2 things that should be of concern to the Indonesian government in preparing for the industrial revolution 4.0, namely the importance of efforts to improve the 
quality of human resources owned and the importance of changes to Law Number 13 of 2013 concerning Labor. One of the efforts that can be done by the government in order to improve the ability of Indonesian workers is to specialize through vocational training courses and training which become a necessity for prospective workers to meet future work needs.

Then, there are at least 4 things that need to be regulated in the revision of Law 13 of 2003. First, industrial relations, namely how the relationship between employers and work recipients (workers) is no longer a permanent and static relationship, but is a friendship or partnership. In this relationship, workers may work for a number of different companies. So, in a work relationship like this, the workplace does not have to be monotonous in a building and the time is flexible.

Second, employ cost. Calculation of payment can be hourly, per day, per week or per month, depending on the agreement or agreement and according to the level of expertise. In the context of work relations and payroll systems like this, of course, if there is termination of employment, there is no such thing as severance pay. Third, industrial relations justice. In the new law a case must be regulated as to what is included in the realm of industrial relations justice. Fourth, an agreement was held in the form of cooperation between the government and PT marketing parties in the form of a franchise company and the company to provide distribution in the form of a place around the Minimarket and Mall as a place of entrepreneurship for small traders.

Industry 4.0 will bring disaster to Indonesia if the key to its success, namely improving the quality of human resources, is ignored. Although the unemployment rate in 2016 has been lower since 1998, autonomy is still a serious threat to the unskilled workforce whose role will begin to shift slowly. Then, if the second thing, namely the revision of Law Number 13 of 2013 concerning Manpower, is also ignored, so that it cannot accommodate industry 4.0. As a result, industry 4.0 implementation will not run optimally.

\section{CONCLUSION}

Industry 4.0 brings many changes in human life. Industry 4.0 has fundamentally changed the way people do activities and has a big influence on the world of work. The positive influence of industry 4.0 is in the form of the effectiveness and efficiency of resources and production costs despite the impact on reducing employment. Industry 4.0 needs a workforce that has skills in digital literacy, technological literacy, and human literacy. The government must be able to equip human resources by expanding employment and also provide opportunities to be able to open entrepreneurship in various places of business and franchise businesses such as Alfamart, Indomart, Alfamidi, 212 Mart, and others. This is where the government challenges to continue to study and develop the field of entrepreneurship. Although there are influences from changing times and other scientific developments, middle and lower-level entrepreneurs should be able to be maintained and focus on examining human interactions with various other components in integrated systems in the industry. It is expected that in the future, industrial engineering can have a role in directing the Industrial 4.0 era to progress that provides great value to humanity. 


\section{DAFTAR PUSTAKA}

Halim, Stevani. Industry 4.0. https://medium.com/@stevanihalim/revolusi-industri-4-0-di-i ndonesia-c32ea95033da. Diakses 27 desember 2018.

Irianto, D. (2017). Industry 4.0; The Challenges of Tomorrow. Disampaikan pada Seminar Nasional Teknik Industri, Batu-Malang.

Karnawati, D. (2017). Revolusi industri, 75\% jenis pekerjaan akan hilang. Diambil dari https://ekbis.sindonews.com/read/1183599/34/ revolusi-industri-75-jenis-pekerjaanakan-hilang-1488169341. Diakses 27 desember 2018

Schwab, K. (2017). The fourth industrial revolution. Crown Business Press.

Tjandrawina, R.R. (2016). Industri 4.0: Revolusiindustri. abadini. Dan pengaruhnya pada. Bidang kesehatan dan bioteknologi. Jurnal Medicinus, Vol 29, Nomor 1, Edisi April.

Where machines could replace humans - and where they can't (yet). (2017). https://public.tableau.com/profile/mckinsey.analytics\#!/vizhome/InternationalAutom ation/ WhereMachines CanReplaceHumans. Diakses 27 desember 2018

Pratomo, HB. 2018. https://www.merdeka.com/uang/untung-rugi-revolusi-industri-40-versipresiden-jokowi.html. Diakses 8 januari 2019

McKinsey, Survey. https://public.tableau.com/profile/ mckinsey. analytics\#!/ vizhome/. International Automation/ WhereMachinesCanReplaceHumans) . 